\title{
METHODS OF PROTECTION OF THE PROPERTY RIGHT IN THE LEGAL SYSTEM OF REPUBLIC OF NORTH MACEDONIA
}

\author{
Emine Zendeli \\ Faculty of Law, South East European University, Tetovo, North Macedonia \\ e.zendeli@seeu.edu.mk
}

\begin{abstract}
The article aims to analyze the legal norms that regulate the protection of the property right in the legal system of the Republic of Macedonia. In most cases, the protection of property right is realized through suits; however, our legal system provides for the possibility that the protection of property right can also be realized through the registration of immovable property rights in the respective Public Registries.

Given the fact that in the Republic of North Macedonia the normative regulation of property suits is not contained in a single normative act, but rather extends to several such acts, the article, based on the practice of the high courts, seeks to analyze the legal cases related to property rights that qualify as rights similar to property rights, but which enjoy legal protection provided by law.

The article will mainly elaborate on the basic provisions on property protection suits contained in the Law on Ownership and other Real Rights (2001). However, in this context, the provisions on property protection that are contained in the Law on Real Estate Cadastre (2008), the Law on Contentious Procedure (2005), the Law on Securing of Claims (2007), the Law on Construction Land (2008), etc., will also be taken into consideration.
\end{abstract}

Key words: Property, protection, suit, court, law. 


\section{INTRODUCTION}

The property right is considered a fundamental human right and is guaranteed by constitutional provisions, international documents, as well as a large number of laws and by-laws. The institute of property right represents a complex legal category, and it is therefore very difficult to give a definition that would encompass all the aspects of its dimensions. According to the theory of civil law, the notion of ownership could be defined as a legal relationship in which, according to the power of the legal norm, a given thing in its entirety belongs to a particular subject (Vedriš \& Klarić 1984, p.32). The provisions of the Law on Ownership and other Real Rights of the Republic of North Macedonia - LPOPR (2001) do not provide a definition of the property institute, but the legislator has merely articulated the ownership authorizations which belong to the owner of the property: "The owner has the right to own, use and dispose of his property at his own discretion, as long as this is not contrary to the law or to another person's right" (Article 8, Paragraph 1, LPOPR). The right to property, as a wider legal power over things and as an absolute subjective right, enjoys full legal protection that enables the protection of other fundamental rights.

The Constitution of the Republic of Macedonia (1990) does not define the property right; however, this does not mean that the highest legal act of the country does not promote the orientation towards a market economy and the guaranteeing of the property right. The constitutional-legal concept of property right is broader than the traditional civil-legal concept, as it encompasses all real rights and other similar rights. Article 8, paragraph 6 of the Constitution confirms the inviolability of the property right, as one of the highest values of the constitutional order. The Constitution expressly and unequivocally guarantees the property right and the inheritance right (Article 30, paragraph 1, CRM). Further, the Constitution proclaims the social character of the right to property, which states: "The property establishes rights and obligations and as such, it should serve for the good of the individual and of the community" (Article 30, Paragraph 2, CRM). The state regulates and ensures the protection of all types of property right and guarantees that no one may be deprived of or restricted from the property and the rights deriving therefrom, except in situations where the public interest, established by law, is concerned, whereupon fair compensation is guaranteed, which cannot be lower than the market value (Article 30, paragraphs 3, 4, CRM).

The protection of the property right urges the protection of the principle of legal security and the confidence in the legal order. This protection, as part of the realization of constitutional legal warrantees, covers several aspects and is foreseen in most legal branches. Although there 
is no doubt that the most important and complete protection of property right is ensured within the civil law, namely, within the real property law (Brežanski 2002, p. 295-333), property rights are also protected within other legal branches such as the criminal law, constitutional law, economic law, labour law, etc. Depending on the legal basis of the claim and the type of norms regulating the type of procedure, the protection of property right can be carried out in court proceedings (Contentious, non-Contentious, enforcement, land books, and criminal) in the proceedings before administrative bodies (expropriation) and other public authorities. In addition, under certain conditions, after all legal means have been exhausted before domestic legal institutions, the property right is also protected before the European Court of Human Rights (Article 1, Annex Protocol to the ECHR).

The protection of the property right in the legal system of the Republic of Macedonia is mainly done through suits, as well as in other ways, such as by registering immovable property rights in the relevant public registers, etc.

The normative regulation of property suits in the legal system of the Republic of Macedonia is contained in several laws. The basic provisions on claims for protection of the property right are contained in the Law on Ownership and Other Real Rights (Art. 156-163). Opportunities for initiation of property claims for certification and for major interference are also provided in the Law on Contentious Procedure (Art. 177-188 - LCP).

The group of suits for the protection of property rights widely includes the suits for changing, namely, for deleting the registration of rights in the Real Estate Cadastre (Article 238, Law on Real Estate Cadastre - REC).

The division creditors protect their property right, in bankruptcy proceedings, through separate suits. Division creditors who do not have the capacity of bankruptcy creditors are those who, under any real or personal rights, can prove that a particular thing does not belong to the bankruptcy measure and that they have the right to separate the thing according to the rules that apply for exercising those rights outside the bankruptcy procedure (Article 125, paragraph 1, Bankruptcy Law - BL).

The protection of the property right in criminal proceedings is realized by the provisions that regulate the legal property claim for restitution of property, which is primarily based on the provisions of Article 156 of the Law on Ownership and Other Real Rights. 


\section{THE PROTECTION OF PROPERTY RIGHT UNDER THE LAW ON OWNERSHIP AND OTHER REAL RIGHTS}

The provisions of the Law on Ownership and other Real Rights of the Republic of Macedonia have regulated several property suits that protect the property right, such as the property claim for restitution (rei vindicatio), the suit of the assumed property owner (actio Publiciana), negatory suit (actio negatoria), suit for protection of co-ownership, namely, joint ownership, etc. Ownership suits act erga omnes - i.e. against all persons who have taken possession of the property or have disturbed the owner. Ownership suits differ from suits arising from obligations because they are designed to protect absolute subjective rights.

\subsection{PROPERTY SUIT FOR RETURNING THE ITEM (THING) (REI VINDICATIO)}

Rei vindicatio is a suit by which the plaintiff demands that the defendant return an item that belongs to the plaintiff. It may be used only when plaintiff owns the thing, and the defendant is somehow impeding the plaintiff's possession of the thing. In practice, it is one of the most frequently used suits. (Gams \& Petrović 1980, p. 259).

Article 156 of the Law on Ownership and Other Real Rights states the following: "The owner can request with a suit from the holder the return of an individually returned item. The owner must prove that $\mathrm{s} / \mathrm{he}$ has the right of ownership over the item whose return is requested, as well as that the item is in the factual possession of the defendant.

The active legitimacy to initiate this suit belongs to the owner of the item, who does not have the item in direct possession. The owner of the item may be the active legitimate, either as a direct or an indirect possessor (Gavella, Josipović, Gliha, Belaj \& Stipković, 2007, p. 593). An active owner is also the owner of the etage ownership with regard to the particular part (whereas, with regard to real estate as a whole, s/he has the right of protection as a co-owner of the item) (Gavella, Josipović, Gliha, Belaj \& Stipković, 2007, p. 593). The builder of a construction building, built without a construction permit, enjoys legal protection provided for the owner (Article 121, paragraph 1, Law on Ownership and other real estate rights - LOORER) until the legalization or demolition of that object, based on a decision of the competent authority. The expropriation user, after acquiring ownership over the expropriated immovable property (omnipotent verdict), has the right to claim, through a property suit, the protection of the 
acquired property right by submitting possession of the immovable property (Rašović, 2010, p 205).

Since, in the infringement suit, the claim is action-related, it is included in the group of condemnatory suit. The plaintiff will not exercise his right to legal protection through the force of the condemnation judgment, but only when the action is carried out, at the last instance and in the enforcement procedure. The right to sue for the return of the item as suchdoes not expire.

In order to initiate a suit, the following conditions have to be met:

a) The ownership right on the item should exist;

b) The item should be in possession of the defendant;

c) The identity of the item should be confirmed.

The procedure for proving the right of ownership depends on what the item is about and how the property has been acquired. In the original acquisition, the owner must prove that he has fulfilled the conditions for acquiring the property right in the manner prescribed by law. When it comes to derivative earning/acquisition, the owner must prove the legal ground (iustus titulus), the manner of earning/acquisition (modus acquirendi) and the ownership of the predecessor. This way of proving requires to find that predecessor that has met the conditions for the original acquisition of property right in the range of plaintiff's ancestors, which can be a very difficult and very long process (probatio diabolica - the devil's proof) (Spaić, 1971, p. 641). Since the right of ownership in certain cases can also be acquired by a court decision or another competent body, the plaintiff can prove his right also by presenting such a decision before the court.

The owner has the right to request the delivery of the item by any person who has unjustly taken possession of it. For this procedure, it is important for the defendant to keep the item without a legal basis or according to a legal basis that was dropped before the suit was initiated.

Passively legitimated in this proceeding is the possessor of the item, regardless if $\mathrm{s} / \mathrm{he}$ is a dependent or an independent possessor. The owner has the right to demand the return of the property from the possessor bona fide, unless the latter has acquired the ownership from the non-owner (Spaić, 1962, p.272). The bona fide possessor must deliver the item in the state in which it was at the time the suit was initiated. If the direct possessor holds the item as a subordinate/dependent possessor, he may be protected from the claim for returning the item by 
appointing the independent direct possessor (nominatio auctoris) from whose possession he has derived his possession (Article 198, paragraph 1, LCP).

The plaintiff must prove that at the time of the judgment the contested item is in the possession of the defendant. The real-legal character of this suit lies in the fact that it is permissible not only to the person who took possession, but also to any other person who holds the disputed item.

The owner must individualize the item on which the procedure is being conducted. Items that cannot be individualized cannot be the subject of a re-indictment suit. The individualization of the disputed item should be done according to the essential features of the item or based on some signs that distinguish it from other items of the same kind. Real estate is most often marked by data and signs from public books. Items that cannot be the subject of a property right may not be the subject of this suit.

If the defendant loses possession of the item after the Contentious Procedure has begun (lis pendens), the passive legitimating does not cease for him, but the plaintiff must prove the existence of possession until the initiation of the suit. If, at the time of initiation of the suit, the defendant was not the possessor of the item, while he takes possession of it in the course of the proceedings, the court is likely to accept the claim because it is adjudicated on the facts existing at the time of termination of the main hearing (Triva, Belajec, Dika, 1986, p. 460).

The possessor's objections: The possessor has the right to refuse the submission/return of the item if he has a right to possession, which may be of a legal-binding nature, of a legal-real nature or another type of nature (Radošević B.br. 11/07, p. 564). The possessor can be defended by peremptory and dilutive objections against the creditor's claims. In the legal theory, the objections are divided into objections, which deny the claim, objections, which annul the claim, and objections, which postpone/delay the claim.

\subsection{SUIT BY THE PRESUMED OWNER (ACTIO PUBLICIANA)}

The provisions of the actio publiciana have been contained in Article 160 of the Law on Ownership and other real rights. It states the following: "The person who has acquired an individually determined item on a legal basis and in a legal manner, and did not know and could have not known that he had not become the owner of the item (presumed owner), has the right to request its return from the conscientious holder who has the item without legal basis or on a weaker basis (Paragraph 1 of the LOORR). 
The actio publiciana cannot be considered a real property suit, because the plaintiff has to prove that, instead of the ownership right, the item whose return he is asking for, has been acquired on a legal basis and in a legal manner, and did not know and could have not known that he had not become the owner of the item (presumed owner) (Paragraph 1 of the LOORR). Therefore, the plaintiff has to prove that he has a qualified ownership, i.e. that the ownership is legal, real and bona fide.

Based on the construction of this suit itself, we can see that we are talking about contradicting legal grounds of possession by two persons, each of whom claims that has a stronger ground on possessing the item. This conflict of legal grounds has been resolved by the provision of second paragraph of the LOORR (though it is not complete as such), which says the following: "When two persons consider themselves presumed owners of the same item, the stronger legal basis belongs to the person who has acquired the item as burden compared to the person who has acquired the item not as burden. If the legal basis of these persons are of the same strength, the person who has the item has the priority. The right to submit a suit from paragraph 1 of this Article does not expire.

The publiciana suit largely resembles a re-indictment suit and is an alternative remedy for legal property protection. Like other property suits, this suit takes its roots in Roman law, while it was named after Praetorian Publicius before the end of the Republic (Bujuklić Ž., 2006, pp. 102-103). Since this suit enables the achievement of the goal without the need for a particular burden of proof and without rigorous formalism, it is recognized by all Contemporary legal systems. It is understandable that such a suit will not succeed against the owner. In this suit, the parties contend their legal grounds for possession, while the one with a stronger basis will be served with the presumption of ownership. However, the question can rightly be raised as to whether the legal basis of the publiciana suit is really the presumed ownership, as the LPORR states, or the independent and qualified possession and stronger right of possession of the item. It would be wrong to think that the basis of the suit may be something that is presumed, so we conclude that the legal basis of this suit is precisely the stronger right of possession (Mulabdic 3-4 / 11, pp. 15-21). Therefore, it would be fairer if the publiciana suit were called a suit according to the stronger basis of possession of the thing. This suit also serves the owner himself, because often, proving ownership, especially of the predecessor, is virtually impossible due to certain circumstances (probatio diabolica). The plausible termination of this Contentious process does not constitute a problem so that the parties thereafter could file a property claim 
for restitution because the proven ownership, as a broader right, is more powerful than the strongest proven right of the right to possession.

\subsection{NEGATORY CLAIM (ACTIO NEGATORIA)}

The right of ownership is not only violated by the taking of the item from possession, but also by actions that disturb the owner in the course of realizing his property authorizations. The negatory suit is a property suit, which is initiated in the event of an owner's disturbance (Babic I., 2008, p. 247). Thus, it is not the case that the disputed property was seized from the possession of the owner, but that the property right was disturbed in another way, namely, the partial damage to property (Stojčević, 1960, p. 164). Regarding this issue, the legislation in the Republic of Macedonia states: "If a third party disturbs the owner or the presumed owner in the accomplishment of the right in a different manner, and not by confiscating the item, the owner or the presumed owner can request for this disturbance to stop by a suit" (Article 161. Paragraph 1. LPORR). It does not matter whether or not these actions have caused harm, and whether the perpetrator's fault exists.

With regard to this type of suit, the plaintiff has to prove that:

a) $\mathrm{s} / \mathrm{he}$ is the qualified owner of the item

b) there is an ungrounded disturbance

c) the defendant is the person who has committed the disturbance act

The ownership right will be proved in the same manner as in the case of the suit on returning the item and the publiciana suit.

The ungrounded disturbance may occur by affirmative action or non-action, that is, by failing to do what was mandatory to be done, preventing the owner from using his own property; by exercising any rights not belonging to the defendant (e.g. passage servitude); through harmful emissions (Article 11, LPORR); through permanent damage to the item; through the collection of stones, rubbish and other debris on foreign soil; by using a foreign wall for one's own needs (placing ads, etc.). Verbal disturbance does not constitute grounds for negatory suits, and neither is relevant the disturbance that is a consequence of a natural event or an accidental event, namely, of force majeure. Disturbances most often occur in immovable property, but may also occur in movable property (Lazarević, 2011, p. 468). Most of the acts of disturbance of the owner's real estate ownership come from emissions, in which the basis of responsibility lies in 
the infringement of the "norm of tolerance" between neighbours. This is not a matter of liability by fault, mistrust or the execution of a right contrary to the purpose, but by the basis of establishing the balance between two or more private interests. Although emissions are neighbouring rights, they do not have to necessarily come from the neighbouring real estate. Emissions and other harmful effects not only endanger the right to property, but can also endanger the right to health, and therefore there is a growing emphasis on the need to apply norms on emission in order to protect human rights, by bypassing neighbouring rights (Gliha 2003, p. 60).

The plaintiff must prove that it is the defendant who committed the act of disturbance. He may be the person who carried out the disturbance, but also the person on whose order it was carried out, namely the person in whose favour the disturbance was committed, and he accepts the same.

The claim is directed to order the respondent to cease disturbance and to take measures to prevent its recurrence in the future. Depending on the manner of the disturbance, the plaintiff will seek a restitution or termination of the actions causing the disturbance. To a certain extent, this suit may also correspond to the suit seeking to avoid harm (ecological suit) (Article 143 LO).

The owner or the presumed owner, as well as the co-owner and joint owner, who must have direct or indirect possession of the item, have active legitimacy for initiating the negatory suit. The owner must prove that he owns the property, while the presumed owner must prove the facts on the basis of which his property right is presumed. The plaintiff must prove that the disturbance exists, but not the fact that this disturbance is unlawful. Legal protection against distress may not be sought by persons who hold the item in subordinate and direct possession, regardless of whether that possession is based on a real or binding right. According to this, nonowners do not have active legitimacy to participate in this procedure.

Passive legitimacy in this procedure has the person who disturbs the owner with no reason, regardless of whether he has undertaken this disturbance for himself and on his own behalf or for the benefit of third parties. Of course, the defendant cannot be the actual holder, as this would lead to the initiation of the reinvindicatoria claim. The person on whose order the disturbance is committed or the person in whose favour the disturbance is committed, while he additionally approves it, can also be the defendant (Vedriš \& Klarić, 2004, p. 292.). If due to the disturbance the owner has been harmed, he is entitled to compensation under the general 
rules of the LO, on the liability under the presumed guilt or under the principle of objective liability (to the dangerous object and the hazardous activity) (Articles 159-198, LO).

\subsection{THE PROTECTION OF THE CO-OWNER AND THE JOINT OWNER}

The system of legal-ownership protection (reinvindicatoria suit, negatory suit, publiciana suit, declaratory suit, secession suit, etc.) also applies to the co-owner. However, the co-owner is not obliged to demand the return of the whole item. The co-owner, or joint owner, has the right to a suit for protection of the right to ownership of the whole object (Article 162, LOORR). The co-owner can ask for legal/court protection from the other co-owner, when s/he hinders or limits the exercising of the factual power.

Each owner of the joint item has the right within the legal-ownership protection system related to the item in its entirety. Joint co-owners have no right to ask for protection over parts of the item, because their parts have not been determined ideally or really (Article 59, LOORR).

\section{THE DIRECT INTERVENTION SUIT}

According to Article 188 of the Law on Contentious Procedure, the person, who completely or partially requests an item or right wherefore litigation is ongoing between other persons, can sue both parties in a single suit with the court where the litigation is ongoing, until the procedure is concluded in a legally valid manner.

The plaintiff in this proceeding is the person who requires the item in full or in part or the right in relation to which the proceedings are being conducted, while the defendants are the persons among whom the proceeding is in progress. This case is an indispensable co-litigation (Article 186, paragraph 1, paragraph 3, LCP), because the suit must involve both parties to the ongoing proceedings. It is not excluded that the suit can only be initiated against the holder of the item, but in that case all the characteristics will apply, as in any suit (regarding local competence, the value of the item of dispute, etc.), but the attraction of subject and local competence will not apply. 


\section{THE SUIT CONFIRMING THE RIGHT TO OWNERSHIP (DECLARATORY SUIT)}

The plaintiff may request, through a suit, that the court only verify the existence, namely, nonexistence of any right or legal relationship, or the authenticity, namely, the non-authenticity of any document. Such a suit may be initiated when the plaintiff has a legal interest therein. In cases where the final decision depends on whether or not there is any legal relationship, which has become contested during the course of the procedure, the plaintiff has the opportunity to file a request, in addition to the existing one, for the court to establish that such a relationship exists, or not, if the court is competent to do so and this will not be considered a change of the suit.

Of the most interesting suit claims for verifying ownership are those in which the publician owner does not register his right to a real estate cadastre under the Law on Real Estate Cadastre ('Official Gazette of the Republic of Macedonia' No. 7/2013) - LC). In this case, he should ask for a confirmation of the right to ownership through a suit, except for cases when that specific right has been obtained by a court decision or another state body.

The right of ownership, despite the fact that it is not registered in the real estate cadastre, will be acquired by the force of law if the conditions for acquiring the property right on the basis of the statutory limitation are fulfilled (Articles 124-125 LOORR). As there is no relevant document as a basis for registration in the acquisition of the ownership right with a winning prescription (unless the competent authority of state administration has ruled on the basis of Article 91 of the Law on Construction Land), the ownership right will be able to be registered on the basis of a judgment establishing that he/she has acquired the right of ownership with a winning statutory limitation.

For this purpose, the plaintiff must have filed a claim for certification related to Article 177 of LCP, persuading the court that there is a legal interest for the claim, as such a judgment will serve as a legal act to register the property right in the real estate cadastre. The person registered in the real estate cadastre will be the defendant. The right to ownership without being registered in the real estate cadastre can also be obtained in other cases, e.g. construction in someone else's land without permission (Articles 117, 118, 119,120 of the LOORR); natural actions related to the displacement of the water flow bed (Article 131, LOORR); the emergence of an island (Article 132, LOORR); the real estate abandonment (Article 135, LOORR); acquiring with 
inheriting (Article 153, LOORR); acquiring with a decision of a state body (Articles 154, 155 LOORR).

\section{THE PROTECTION OF OWNERSHIP RIGHT IN A BANKRUPTCY PROCEDURE}

A Bankruptcy Proceeding aims to achieve a collective settlement of the creditors of the bankruptcy debtor through liquidation (conversion into cash) of the debtor's property and distribution of the proceeds to the creditors (Article 3, Bankruptcy Law - 2006). In addition to bankruptcy creditors, other categories of creditors who do not have the capacity of bankruptcy creditors are entitled to collection. Such are the cessation creditors who, by virtue of any real or personal right, can prove that an item is not part of the bankruptcy measure and that they have the right to divide the item (Article 125 Bankruptcy Law - 2006). Such a creditor has active legitimacy for initiating a suit for the cessation of the item, while the bankruptcy debtor represented by the bankruptcy administrator has passive legitimacy.

\section{THE PROTECTION OF THE OWNERSHIP RIGHT IN THE CRIMINAL PROCEDURE}

The protection of property right can also be carried out in criminal proceedings. The legalproperty claim related to the restitution of the item, compensation of damages or nullification of the juridical act created by the commission of the criminal offense at the request of the authorized person may be examined in criminal proceedings (Article 97 LCP). In this context, according to Article 103 of the Criminal Code, "If the legal and property claim refers to returning an object, and if the court establishes that the object belongs to the injured party and is kept by the accused or by some other participant in the crime or by a person to whom the object was given for safekeeping by them, in its judgment, the court shall indicate that the object is to be returned to the injured party." During the criminal procedure, according to the provisions valid for the enforcement procedure, upon proposal by the public prosecutor and other authorized persons, provisional measures may be imposed in order to safeguard the legal and property claim that resulted from the criminal offence (Article 106 LCP). According to Article 107, paragraph 2 of the Criminal Code, "If several injured parties are in a dispute over the ownership of the objects, they shall be referred to litigation, and the court in the criminal procedure shall only rule on the safeguarding of the objects as a provisional security measure." 


\section{THE PROTECTION OF RIGHTS SIMILAR TO THE OWNERSHIP RIGHT}

The provisions of Article 36 of the Law on Real Estate Cadastre state that data from the records of illegally constructed buildings and temporary buildings are issued as an evidentiary list and list of temporary objects and that these lists are not public documents through which the right of ownership of the real estate could be proved. Although these lists are not considered as public documents, it is stipulated that on a building constructed without a permit, by the very fact of construction, the builder does not acquire the right of ownership, but until the legalization or demolition of the building on the basis of a decision of the competent body, the person enjoys legal protection that belongs to the owner. According to Article 136 of the Law on Real Estate Cadastre, temporary objects are registered in the list of temporary objects and enjoy legal protection, even though they are not registered in the real estate cadastre.

\section{EXPIATION SUITS FOR PROTECTING THE OWNERSHIP RIGHT}

When multiple persons have concluded with the alienator suits for acquiring ownership of the same real estate, ownership will be acquired by the person who first required the registration in the real estate public records (Article 152, LOORR).

The Erasing of the registered ownership and the registration in one's own benefit can be requested by a person from whom the alienator has alienated the real estate and given to be governed. The claim can be initiated within three years from the day of its registration. Expiation claims are new in our legal system. Such claims could not be foreseen at all until the adoption of the Law on cadastre measurements and registration of rights on real estates, because a system of registering these rights in the Republic of Macedonia did not exist at all (apart from in-tabulation records/books).

Article 177 of the Law on Real Estate Cadastre states that "Any person having a legal interest may seek expiation of what has been registered within a period of three years from the issuance of the certificate, namely from the publication of the ruling on conversion of data from the land cadastre into the cadastre of real estate in the Official Gazette of RM. The effect of expiation is related to the withdrawal of what is recorded in the cadastre. However, such a suit is usually related to a suit under Article 152 of the Law on Property and Other Real Rights, so that its effect is on the exercising of the protection of the property right. The idea of the expiation suit is to prevent the incorporation of the "tabular possession" institute into the legal system, that is, 
the acquisition of ownership of the real estate property, even though that property has never been owned by the person who has been registered in the real estate cadastre as its owner, whereas, in the meantime, the right to publiciana ownership (presumed owner), or by virtue of statutory suit and lawful possession has been acquired by the other person.

\section{CONCLUSION}

The right to ownership, as a broader legal power over items, enjoys comprehensive legal protection. This protection includes in itself several aspects. The legal-real aspect of the protection of the right to ownership is the most important and has been positioned at a broader dimension of the Law on Ownership and Other Real Rights. The following suits protecting the ownership right, such as rei vindicatio, actio publiciana dhe actio negatoria, which protect the ownership from being alienated his item, or the disturbance of the owner in another manner, excluding the alienation of the item, originate from the Roman law. The right to ownership is not protected only in the real right, but also in other branches of the judiciary, i.e. in the constitutional law, the criminal law, economic law and labour law. Apart from court proceedings (Contentious, non-Contentious, enforcement, land books, criminal), the right to ownership enjoys protection in procedures before administrative bodies or other state bodies. In addition, under certain circumstances, when all such legal measures have been exhausted, the right to ownership can also be defended before the European Court of Human Rights. 


\section{REFERENCES}

- Babić I., Građansko pravo - Uvod u građansko pravo i Stvarno pravo, Banja Luka, 2008, str. 247.

- Brežanski Jasna „Zaštita prava vlasništva“, Zbornik Pravnog fakulteta Sveučilišta u Rijeci, br. $1 / 02$,

- Bujuklić Ž., Forum romanum, Rimska država, pravo, religija i mitovi, Drugo izmenjeno i dopunjeno izdanje, Beograd, 2006,

- Gavella Nikolla, Josipović Tatjana, Gliha Igor, Belaj Vlado, Stipković Zlatan, Stvarno pravo, Svezak prvi, II. izmijenjeno i dopunjeno izdanje, Zagreb, 2007, p. 593,

- Gams A. \& Petrović M., Osnovi stvarnog prava, osmo, novim propisima prilagođeno, izdanje, Beograd, 1980, p. 259.

- Gliha I., Novo uređenje susjedskih odnosa u svjetlu prilagodbe hrvatskog građanskopravnog poretka europskim, u Budimpeštanski simpozijum, Doprinos reformi stvarnog prava $u$ državama jugoistočne Evrope, Bremen, 2003,

- Lazarević D., Službenosti i susedsko pravo, Prvo izdanje, Beograd, 2011, str. 468.

- Mulabdić S., Teorijski i praktični aspekti publicijanske tužbe, Pravna misao, br. 3-4/11, str. 15-21.Radošević B., “Građanskopravna zaštita prava svojine”, Pravni život, br. 11/07,

- Rašović, Z., Stvarno pravo, četvrto izmijenjeno i dopunjeno izdanje, Podgorica, 2010,

- Spaić, V. Građansko pravo, Opšti dio i Stvarno pravo, Sarajevo, 1971,

- Spaić V., Osnovi građanskog prava II, Stvarno pravo, treće dopunjeno i izmijenjeno izdanje, Sarajevo, 1962,

- Stojčević D., Rimsko pravo, sveska prva, sedmo izdanje, Beograd, 1960,

- Triva S, Belajec V. i Dika M., Građansko parnično procesno pravo, Zagreb, 1986,

- Vedriš M. i Klarić P. D., Osnove imovinskog prava, 5. izdanje, Pravni fakultet, Zagreb, 1984,

\section{Normative Acts, Codes, Laws:}

- Kushtetuta e Republikës së Maqedonisë-KRM.

- Protokolli shtesë, Konventa për Mbrojtjen e të Drejtave të Njeriut dhe të Lirive Themelore Konventa Evropiane për të Drejtat e Njeriut (KEDNj).

- Ligji për pronësi dhe të drejta të tjera sendore, ("Gazeta zyrtare e Republikës së Maqedonisë" nr. 18/2001; 173/2007; 92/2008; 139/2009; 35/2010 - LPDTS.

- Ligji për procedurë kontestimore, ("Gazeta zyrtare e Republikës së Maqedonisë" nr. 79/2005; 110/2008; 83/2009; 116/2010; 7/2011; 24/2015) - LPK.

- Ligji për katastër, "Gazeta zyrtare e Republikës së Maqedonisë" nr. 55/2013; 41/2014; 67/2014; 115/2014; 116/2015; 153/2015; 192/2015; 61/2016; 172/2016)-LK.

- Ligji për falimentim, "Gazeta zyrtare e Republikës së Maqedonisë" nr.34/2006.

- Ligji për marrëdhëniet e detyrimeve, ("Gazeta zyrtare e Republikës së Maqedonisë" nr. 18/2001; 4/2002; 5/2003; 84/2008; 81/2009; 161/2009) - LO.

- Ligji për tokë ndërtimore ("Gazeta zyrtare e Republikës së Maqedonisë" nr.15/2015)- LTN.

- Ligji për procedurë penale, ("Gazeta zyrtare e Republikës së Maqedonisë" nr. 150/2010; 51/2011; 100/2012; 142/2016) -LPP.

- Ligji për matje, katastër dhe regjistrim të të drejtave mbi paluajtshmëritë, ("Gazeta zyrtare e Republikës së Maqedonisë’nr. 27/1986)-LMKRDP 